\title{
EMBLEM. LXII.
}

Die kent zïnplicht en fuelt niet lichtu.

En fchutter die het vvit vvilt fonder fchae geraken En fal dat nimmermecr op harde fteenen maken, Want anderfints den fchicht die vveer gedreven vvert Geraeckt den fchutter felf, en quett hem in het hert. Ghy die uvv' kloeck verftant en wel begaefde reden Wilt eerelick tot lof van uwen naem befteden, Laeckt die ghy laecken moet, prijft die prijfweerdig fijn, It dat ghy anders doet ghy brengt u felf in pijn. 


\section{E MBLEM. LXII].}

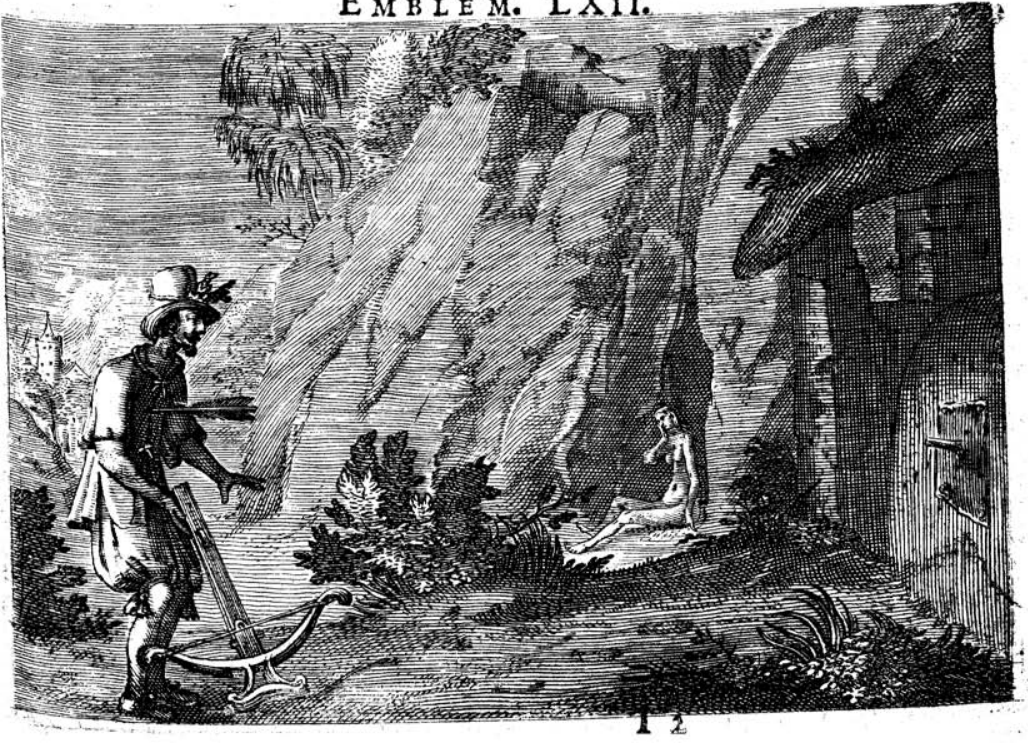

